\title{
Michael J. Samways: Insect conservation: a global synthesis
}

\author{
CABI, 2019, 540 pp, $£ 125.00$ (hardback, ISBN 978-1-78924-168-6), £55.00 (paperback, ISBN \\ 978-1-78924-167-9). https://www.cabi.org/bookshop/book/9781789241686/
}

\author{
Thomas Fartmann ${ }^{1}$
}

Received: 3 March 2020 / Accepted: 3 March 2020 / Published online: 13 March 2020

(c) The Author(s) 2020

In the era of Anthropocene, the recent loss of biodiversity in general and insects in particular is one of the greatest challenges to humanity. Although entomologists have been aware of insect declines since the nineteenth century, insect conservation is a relatively young discipline. As a consequence, a global synthesis that presents an up-to-date overview of the knowledge on insect conservation and strategic ways forward to halt the loss of insects was lacking so far.

Each of the chapters of the book consists of (i) a text with extensive references, (ii) a summary of the main findings by excellent illustrations with detailed captions and (iii) focused key points at the end of the chapter. The book can be divided in 6 parts consisting of 13 chapters. It starts with a chapter on the foundations for insect conservation. The next four chapters address the three operational scales of insect conservation: (i) the conservation of landscapes (coarse filter), (ii) the conservation of landscape features (meso-filter) (Chapters 2 and 3 ) and (iii) the conservation of a focal species or groups of species in a particular area (fine filter, Chapters 4 and 5). The following four chapters focus on the conservation of insects in different habitats or groups of habitats, namely farmland (Chapter 6), forests, grasslands and caves (Chapter 7), freshwater ecosystems (Chapter 8) and urban ecosystems (Chapter 9). Chapter 10 looks at the importance of habitat restoration for insect conservation. The next two chapters consider ecological assessment (Chapter 11) and monitoring (Chapter 12) in insect conservation. The book concludes with a chapter on the efforts that are necessary for a future-proof world for insects (Chapter 13).

Michael J. Samways is a well-respected entomologist and one of the founding fathers of the scientific discipline of

Thomas Fartmann

t.fartmann@uos.de

1 Osnabrück University, Osnabrück, Germany insect conservation. The author's vast experience, his enthusiasm and love for insects shines through every chapter in Insect Conservation: A Global Synthesis. This comprehensive textbook summarizes the current knowledge of insect conservation at a global scale. The text is easy to read and well-documented, with a reference list including more than 110 pages. The combination with the excellent summarizing drawings is unique. It is an infinite source of knowledge. Everyone will find something new or better explained in this book.

In conclusion, it is a passionate plea to value and conserve insects in a rapidly changing world. Although we still lack much knowledge, Michael Samways shows that we know enough to act now and what we should do to conserve the fascinating world of insects for future generations. For everyone who is interested in insects or engaged in nature conservation the book is a must.

Acknowledgements Open Access funding provided by Projekt DEAL.

Open Access This article is licensed under a Creative Commons Attribution 4.0 International License, which permits use, sharing, adaptation, distribution and reproduction in any medium or format, as long as you give appropriate credit to the original author(s) and the source, provide a link to the Creative Commons licence, and indicate if changes were made. The images or other third party material in this article are included in the article's Creative Commons licence, unless indicated otherwise in a credit line to the material. If material is not included in the article's Creative Commons licence and your intended use is not permitted by statutory regulation or exceeds the permitted use, you will need to obtain permission directly from the copyright holder. To view a copy of this licence, visit http://creativecommons.org/licenses/by/4.0/.

Publisher's Note Springer Nature remains neutral with regard to jurisdictional claims in published maps and institutional affiliations. 